\title{
Coverage Analysis of Fire Stations Located in Puebla City and Determination of New Possible Required Locations
}

\author{
Lucero Alejandra Salazar Jáuregui, Diana Sánchez-Partida, \\ José Luis Martinez-Flores \\ Popular Autonomous University of the State of Puebla (UPAEP University), Puebla, \\ Mexico \\ \{Luceroalejandra.salazar, Diana.sanchez, Joseluis.martinez01\}@upaep.mx
}

\begin{abstract}
The growing population in Puebla City these last couple of years entailed the expansion of its original urban area. The most recent settlements have established on areas that are highly exposed to natural disasters, thus, requiring the proper emergency service coverage provided by Fire Stations. To assure this kind of service coverage, the current fire stations in Puebla City were evaluated through mapping tools and given parameters, in order to recognize the capacity to satisfy the entire city's service demand. Based on the coverage analysis it was determined the need for an extra facility. The characteristics of the problem suggested that the most appropriated model to use is the Maximum Coverage Model, which is adapted for Lingo software to determine the optimal location to place the new fire station, looking for the full or largest possible coverage.
\end{abstract}

\section{Introduction}

The expansion of the urban area of Puebla City began in the middle of the twentieth century as a result of the exponential population growth. According to the National Institute of Statistics and Geography (INEGI), in the last 10 years the population in Puebla has increased by $12 \%$ and it shows a trend to settle up towards the southern part of the city. Due to topographic, climatologic and urban design characteristics, many of these new settlements are highly vulnerable to different types of risks caused mainly by natural disasters such as mudslides, fires and floods. The Fire Department of Puebla City has implied that the vulnerability for these new urban areas could be higher, considering that the response time for emergencies might take longer due to the lack of closer fire stations.

As stated by the Public Security Law of Puebla State, in case of an emergency, the first unit to provide the service must arrive within the first 10 minutes after a call. Although, if the service required is not a priority or there are not available resources to cover the service immediately, the response time could take between 15 and 25 minutes. Nowadays, the emergencies that occur in these new communities are covered by any of the current seven fire stations located in the main urban area; however, due to the distances between these communities and the nearest fire stations, the emergency response time could take up to 50 minutes. 
The Fire Department of Puebla recognizes the need for more fire stations that can provide the emergency service for these communities within a fewer response time. Nonetheless, the low population density of these communities (due to its recent creation) along with the limited government budget, would not justify installing more than one fire station to provide the required service.

The objective of this research is to analyze the coverage scope of the existing fire stations in Puebla City to be able to identify the service uncovered areas and to determine the optimal location for a new facility, ensuring the full or maximum possible service coverage for the areas that require it.

\section{$2 \quad$ Literature Review}

At present, mapping tools have become a strong support for facility location decisions, especially with the integration of Geographic information systems (GIS).

According to IFMA Foundation [1] "A GIS can be used by facility managers for space management, visualization and planning, and emergency and disaster planning and response, as well as many other applications"

Resent research related to public facilities location relies on the use of two of the main mapping applications that integrate GIS: Esri and Google Maps.

Mosquera [2], in her study of Optimal areas determination for new fire stations located at Bogota based on special analysis tools, combines the use of ESRI with the Analytic Hierarchy Process (AHP), while other authors such as Gu et al [3] employs the use of Google Maps to estimate travelling distances and times in their study Optimization of preventive health care facility locations.

Since Google Maps is a widely known and a user friendly app, we use this webmapping tool to generate part of the data that will be the input for the facility location model. To determine the mathematical model to be used, we refer and briefly describe the most commonly used models for emergency facility locations:

- P-Median model: The objective function is to minimize the average distance between facilities and demanding nodes.

- P-Center model: The objective function is to minimize the maximum distance/time between a facility and the demanding nodes, placing $\mathrm{P}$ number of facilities required.

- $\quad$ Set Covering Model: The objective function is to minimize the cost of placing the required facilities while ensuring that all demanding nodes are satisfied.

Based on the problem features, the model to determine the optimal location for the new fire station must have in consideration the budget restriction. A variation of the Set covering model that fits this requirement is the Maximum Coverage Model.

As quoted by Church and ReVelle [4], "The maximal covering location problem was formulated to address planning situations which have an upper limit on the number of facilities to be sited. The objective of the MCLP is to locate a predetermined number of facilities, $\mathrm{p}$, in such a way as to maximize the demand that is covered".

For this case study, we will use this last model; however, we will not take into account values of demand, as a demanding point will be considered as served as long as it is within a coverage range of any fire station. 


\section{Methodology}

\subsection{Study Area}

The City of Puebla has currently seven fire stations mainly distributed on the central urban area. Figure 1 shows the locations of these fire stations, along with the southern area tentatively considered as uncovered (marked in pink). It also shows two recognized sets of communities in this area. Set 1 includes 5 communities located to the north of a river (Balsas River) and Set 2 includes 5 communities located to the south of the river.

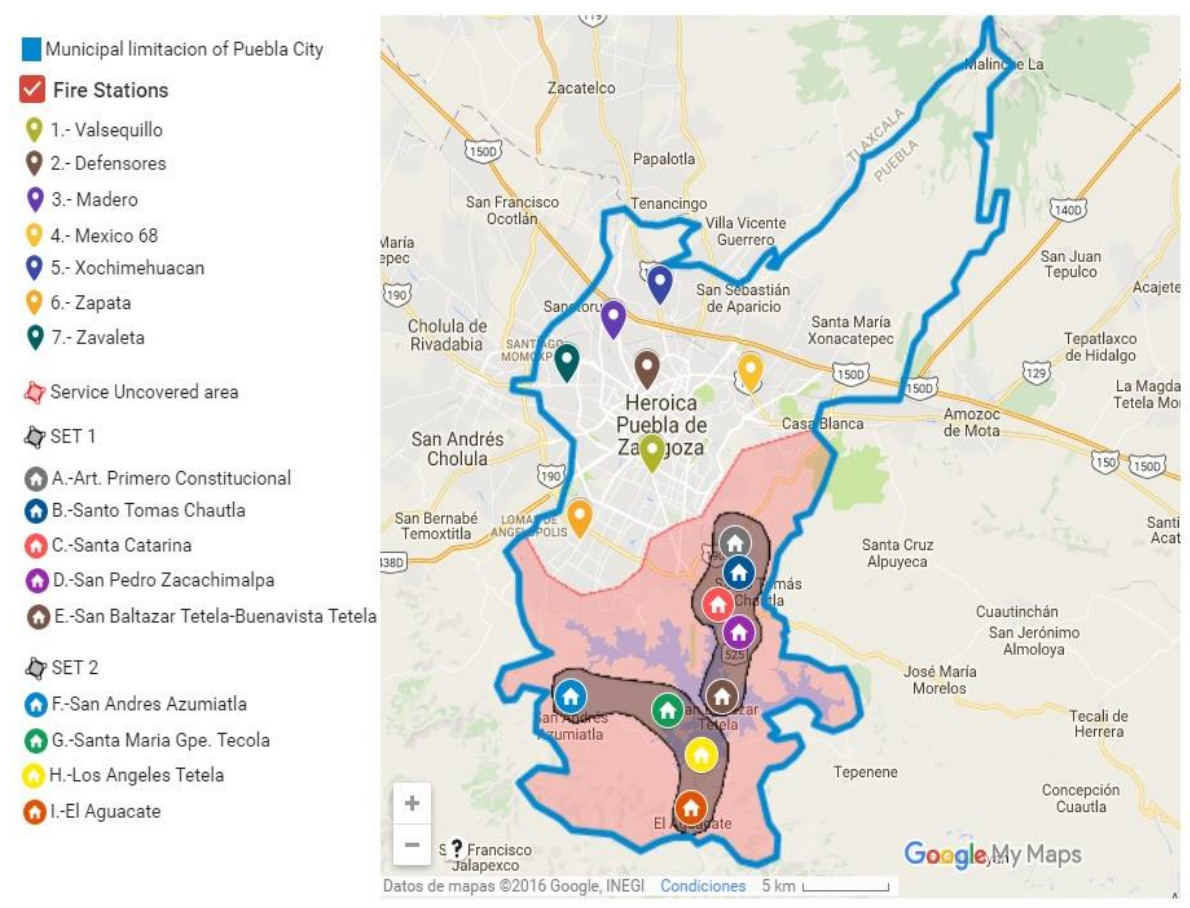

Figure 1. Fire stations, uncovered area and communities within Puebla City.

The coverage analysis consists in detecting the capacity of the current fire stations to satisfy the demand of emergency service for the entire city, considering strictly the law restriction of 10 minutes-first unit arrival. To do so, we need to define firstly the measurement units we will use for the data. Google Maps provides accurate distances between points, as well as estimated times. The estimated times are relative to speed limits and current traffic among others conditions, despite this, fire trucks are allowed to skip some of these laws for emergency situations. Therefore, the measurement unit for data will be only distances. It will be assumed that fire trucks travel at least $1 \mathrm{~km}$ per minute (considering circumstances that may slow it down), so the coverage limit per fire station will be 10 kilometers (based on the 10 minutes-first unit arrival restriction). The analysis will be developed in two parts. First it will be the analyzed the main central urbanized area and then, the south possible uncovered area. 


\subsection{Coverage Analysis}

To analyze the coverage in the central urbanized area, we suppose each fire station represents a node in a network and the arcs of the network are the distances between each fire station. As each node should cover a maximum distance of $10 \mathrm{~km}$, we must assure that the arcs between each node and the closest one is at least $20 \mathrm{~km} \mathrm{(10} \mathrm{km} \mathrm{per}$ node). The matrix of distances between each node is shown in Table 1.

Table 1. Distances between fire stations located in Puebla City.

\begin{tabular}{|c|c|c|c|c|c|c|c|}
\hline $\begin{array}{c}\text { Fire Station } \\
\text { From-to matrix }\end{array}$ & Valsequillo & Defensores & Madero & Mexico 68 & Xochime-huacan & Zapata & Zavaleta \\
\hline Valsequillo & & $17 \mathrm{~km}$ & $22 \mathrm{~km}$ & $23 \mathrm{~km}$ & $26 \mathrm{~km}$ & $18 \mathrm{~km}$ & $23 \mathrm{~km}$ \\
\hline Defensores & $17 \mathrm{~km}$ & & $11 \mathrm{~km}$ & $14 \mathrm{~km}$ & $13 \mathrm{~km}$ & $25 \mathrm{~km}$ & $18 \mathrm{~km}$ \\
\hline Madero & $22 \mathrm{~km}$ & $11 \mathrm{~km}$ & & $17 \mathrm{~km}$ & $11 \mathrm{~km}$ & $23 \mathrm{~km}$ & $13 \mathrm{~km}$ \\
\hline Mexico 68 & $23 \mathrm{~km}$ & $14 \mathrm{~km}$ & $17 \mathrm{~km}$ & & $16 \mathrm{~km}$ & $33 \mathrm{~km}$ & $31 \mathrm{~km}$ \\
\hline Xochimehuacan & $26 \mathrm{~km}$ & $13 \mathrm{~km}$ & $11 \mathrm{~km}$ & $16 \mathrm{~km}$ & & $31 \mathrm{~km}$ & $21 \mathrm{~km}$ \\
\hline Zapata & $18 \mathrm{~km}$ & $25 \mathrm{~km}$ & $23 \mathrm{~km}$ & $33 \mathrm{~km}$ & $31 \mathrm{~km}$ & & $15 \mathrm{~km}$ \\
\hline Zavaleta & $23 \mathrm{~km}$ & $18 \mathrm{~km}$ & $13 \mathrm{~km}$ & $31 \mathrm{~km}$ & $21 \mathrm{~km}$ & $15 \mathrm{~km}$ & \\
\hline
\end{tabular}

Based on the matrix data, it is possible to recognize that each fire station has at least another fire station located within the limit of $20 \mathrm{~km}$, therefore it can be assumed that the current set of fire stations meets the conditions of response coverage for this area. Unlike the central area, the southern area distances matrix (shown in table 2) only considers the distances between each of the communities and the two nearest fire stations (Zapata and Valsequillo).

Table 2. Distances between Zapata and Valsequillo fire stations and the communities in the south area.

\begin{tabular}{|l|c|c|}
\hline \multicolumn{1}{|c|}{ Community / Fire Station } & Zapata & Valsequillo \\
\hline San Andres Azumiatla & $11 \mathrm{~km}$ & $18 \mathrm{~km}$ \\
\hline Santa Maria Gpe. Tecola & $17 \mathrm{~km}$ & $23 \mathrm{~km}$ \\
\hline Los Angeles Tetela & $21 \mathrm{~km}$ & $28 \mathrm{~km}$ \\
\hline El Aguacate & $27 \mathrm{~km}$ & $35 \mathrm{~km}$ \\
\hline San Baltazar Tetela & $17 \mathrm{~km}$ & $15 \mathrm{~km}$ \\
\hline San Pedro Zacachimalpa & $15 \mathrm{~km}$ & $12 \mathrm{~km}$ \\
\hline Santa Catarina & $11 \mathrm{~km}$ & $10 \mathrm{~km}$ \\
\hline Santo Tomas Chautla & $12 \mathrm{~km}$ & $9 \mathrm{~km}$ \\
\hline Art. Primero Constitucional & $13 \mathrm{~km}$ & $9 \mathrm{~km}$ \\
\hline
\end{tabular}

As seen on the estimations in table 2, some of the 9 communities can be considered as covered because they are located within the 10 kilometers condition to any of the 
two nearest fire stations. However, none of these fire stations seems to be able to provide the service within the 10 minutes restriction for all the communities located in this southern area. Therefore, a facility will have to be located closer to these communities to provide the emergency service. It is important to mention that due to the need of utilities such as electricity, gas and water, among others, the facility must be located within a candidate community and not in an average geographical point. In this way, we proceed to generate the distance matrix for all the communities located in this area:

Table 3. Distances Matrix between each of the communities in the south area of the municipal.

\begin{tabular}{|c|c|c|c|c|c|c|c|c|c|}
\hline $\begin{array}{l}\text { From-to } \\
\text { matrix }\end{array}$ & $\begin{array}{l}\text { San Andres } \\
\text { Azumiatla }\end{array}$ & $\begin{array}{l}\text { Santa Maria } \\
\text { Gpe. Tecola }\end{array}$ & $\begin{array}{c}\text { Los Angeles } \\
\text { Tetela }\end{array}$ & E1 Aguacate & $\begin{array}{c}\text { San Baltazar } \\
\text { Tetela }\end{array}$ & $\begin{array}{c}\text { San Pedro } \\
\text { Zacachimalpa }\end{array}$ & $\begin{array}{c}\text { Santa } \\
\text { Catarina }\end{array}$ & $\begin{array}{l}\text { Santo } \\
\text { Tomas } \\
\text { Chautla }\end{array}$ & $\begin{array}{l}\text { Art. Primero } \\
\text { Constitucional }\end{array}$ \\
\hline $\begin{array}{l}\text { San Andres } \\
\text { Azumiatla }\end{array}$ & & $7 \mathrm{~km}$ & $12 \mathrm{~km}$ & $18 \mathrm{~km}$ & $27 \mathrm{~km}$ & $25 \mathrm{~km}$ & $22 \mathrm{~km}$ & $22 \mathrm{~km}$ & $24 \mathrm{~km}$ \\
\hline $\begin{array}{l}\text { Santa Maria } \\
\text { Gpe. Tecola }\end{array}$ & $7 \mathrm{~km}$ & & $16 \mathrm{~km}$ & $10 \mathrm{~km}$ & $16 \mathrm{~km}$ & $34 \mathrm{~km}$ & $27 \mathrm{~km}$ & $28 \mathrm{~km}$ & $29 \mathrm{~km}$ \\
\hline $\begin{array}{c}\text { Los Angeles } \\
\text { Tetela }\end{array}$ & $12 \mathrm{~km}$ & $16 \mathrm{~km}$ & & $7 \mathrm{~km}$ & $7 \mathrm{~km}$ & $25 \mathrm{~km}$ & $26 \mathrm{~km}$ & $26 \mathrm{~km}$ & $30 \mathrm{~km}$ \\
\hline E1 Aguacate & $18 \mathrm{~km}$ & $10 \mathrm{~km}$ & $7 \mathrm{~km}$ & & $8 \mathrm{~km}$ & $26 \mathrm{~km}$ & $27 \mathrm{~km}$ & $28 \mathrm{~km}$ & $31 \mathrm{~km}$ \\
\hline \begin{tabular}{c|} 
San Baltazar \\
Tetela
\end{tabular} & $27 \mathrm{~km}$ & $16 \mathrm{~km}$ & $7 \mathrm{~km}$ & $8 \mathrm{~km}$ & & $4 \mathrm{~km}$ & $8 \mathrm{~km}$ & $8 \mathrm{~km}$ & $12 \mathrm{~km}$ \\
\hline \begin{tabular}{c|} 
San Pedro \\
Zacachimalpa
\end{tabular} & $25 \mathrm{~km}$ & $34 \mathrm{~km}$ & $25 \mathrm{~km}$ & $26 \mathrm{~km}$ & $4 \mathrm{~km}$ & & $3 \mathrm{~km}$ & $6 \mathrm{~km}$ & $9 \mathrm{~km}$ \\
\hline Santa Catarina & $22 \mathrm{~km}$ & $27 \mathrm{~km}$ & $26 \mathrm{~km}$ & $27 \mathrm{~km}$ & $8 \mathrm{~km}$ & $3 \mathrm{~km}$ & & $3 \mathrm{~km}$ & $6 \mathrm{~km}$ \\
\hline \begin{tabular}{c|} 
Santo Tomas \\
Chautla
\end{tabular} & $22 \mathrm{~km}$ & $28 \mathrm{~km}$ & $26 \mathrm{~km}$ & $28 \mathrm{~km}$ & $8 \mathrm{~km}$ & $6 \mathrm{~km}$ & $3 \mathrm{~km}$ & & $4 \mathrm{~km}$ \\
\hline \begin{tabular}{c|} 
Art. Primero \\
Constitucional
\end{tabular} & $24 \mathrm{~km}$ & $29 \mathrm{~km}$ & $30 \mathrm{~km}$ & $31 \mathrm{~km}$ & $12 \mathrm{~km}$ & $9 \mathrm{~km}$ & $6 \mathrm{~km}$ & $4 \mathrm{~km}$ & \\
\hline
\end{tabular}

Considering that each of these communities is a demand point (the nodes in a network), we have to find the optimal location for the new fire station that will provide the service. Due to the low population density in the communities of set 2, the installation of a fire station at any community within this Set not justified. Thus, the fire station facility to install should be assigned to a candidate site in Set 1 and must try to maximize the coverage demand of all the other communities within Set 1 and Set 2. Also, San Baltazar Tetela community belonging to Set 1 cannot be considered as candidate because of its geographical location (exposed to floods).

The data shown in Table 3 will be the input for the Maximum Coverage Model, being $i$ the set of demand nodes ( 9 communities: a, b, c, d, e, f, g, h, i), $j$ the set of candidate facility sites (Only 4 out of the 5 communities from Set 1: a, b, c, d), hi the demand at node $\mathrm{i}, \mathrm{P}=$ number of facilities to locate, and the following parameters:

$\mathrm{Z}_{\mathrm{i}}=\left\{\begin{array}{l}1 \text { if node } i \text { is covered } \\ 0 \text { if not }\end{array}\right.$

$\mathrm{X}_{\mathrm{j}}=\left\{\begin{array}{l}1 \text { If we locate facility at candidate site } j \\ 0 \text { if not }\end{array}\right.$

$\alpha_{\mathrm{ij}}=\left\{\begin{array}{l}1 \text { If demand node } \mathrm{i} \text { can be covered by a facility at candidate site } \mathrm{j} \\ 0 \text { if not }\end{array}\right.$

The model is formulated as follows: 
Maximize

subject to:

$$
\begin{gathered}
\sum_{j} \alpha_{i j} \mathrm{X}_{j} \geq \mathrm{Z}_{i}, \\
\sum_{j} \mathrm{X}_{j}=\mathrm{P},
\end{gathered}
$$

where

$$
\begin{aligned}
& \mathrm{X}_{j}=0,1, \\
& \mathrm{Z}_{i}=0,1 .
\end{aligned}
$$

The objective function (1) maximizes the number of covered nodes. As mentioned previously for this case we do not take into account demand values because we are trying to maximize the amount of communities that can be covered within the 10 minutes restriction time.

The constraint (2) indicates that demand at node $i$ (each of the nine communities) cannot be considered as satisfied unless at least one of the facilities assigned $j$ (any of the 4 communities of set 1), is selected to cover it. This condition of satisfied demand is based on the $10 \mathrm{~km}$ restriction (taken from data of Table 3), if the demand point $i$ is located within the $10 \mathrm{~km}$ of the assigned $\mathrm{j}$ site, then it can be considered as satisfied. In this same restriction, $\alpha_{\mathrm{ij}}$ is a binary variable defined by the capacity of facility assigned $j$ to satisfy demand at $i$.

Second restriction (3) ensures that the number of facilities to place have a limit (P), for this case $\mathrm{P}=1$ due to budget limitations, while restriction 4 and 5 indicate that variables $\mathrm{X}$ and $\mathrm{Z}$ are binaries.

\section{$4 \quad$ Results}

Given the input data, LINGO software was used to solve the model. The results showed that under the 10 kilometers restriction, any of the 4 candidates could pro-vide the service for the communities in Set 1, yet, none of them would be able to cover the communities in set 2 . As there is still a need to install a fire station that can at least reduce the response times compared to the current attention service, a sensibility analysis was generated to evaluate different scenarios in order to recognize the scope of the service under different distance limits.

The starting distance limit for the tests was the $10 \mathrm{~km}$ of the original restrictrion. Following 3 tests increased by 5 kilometers. Results of these tests are shown in Table 4 and the analysis indicates that a significative change happens when the coverage extends to 25 kilometers, which is the distance limit where 7 out of the 9 communities can be considered as covered. However it is not until the distance limit is $27 \mathrm{~km}$ when all of the communities can be considered as satisfied if the fire station is located at Santa Catarina community.

Despite this is still a high response time (assuming $27 \mathrm{~km}=27$ minuts), it is the one that can satisfy all the current communities demand in the fewest time. 
Coverage Analysis of Fire Stations Located in Puebla City and Determination of New Possible ...

Table 4. Results of Lingo for facility location based on distance limit.

\begin{tabular}{|c|c|c|}
\hline $\begin{array}{c}\text { Distance } \\
\text { Limit }\end{array}$ & Facility Location Candidate & Observations \\
\hline $10 \mathrm{~km}$ & $\begin{array}{l}\text { Art. Primero Constitucional } \\
\text { Santo Tomas Chautla } \\
\text { Santa Catarina } \\
\text { San Pedro Zacachimalpa }\end{array}$ & $\begin{array}{l}\text { Following communities can't be covered: } \\
\text { San Andres Azumiatla } \\
\text { Santa Maria Guadalupe Tecola } \\
\text { Los Angeles Tetela } \\
\text { El Aguacate }\end{array}$ \\
\hline 15 & $\begin{array}{l}\text { Art. Primero Constitucional } \\
\text { Santo Tomas Chautla } \\
\text { Santa Catarina } \\
\text { San Pedro Zacachimalpa }\end{array}$ & $\begin{array}{l}\text { Following communities can't be covered: } \\
\text { San Andres Azumiatla } \\
\text { Santa Maria Guadalupe Tecola } \\
\text { Los Angeles Tetela } \\
\text { El Aguacate }\end{array}$ \\
\hline $20 \mathrm{~km}$ & $\begin{array}{l}\text { Art. Primero Constitucional } \\
\text { Santo Tomas Chautla } \\
\text { Santa Catarina } \\
\text { San Pedro Zacachimalpa }\end{array}$ & $\begin{array}{l}\text { Following communities can't be covered: } \\
\text { San Andres Azumiatla } \\
\text { Santa Maria Guadalupe Tecola } \\
\text { Los Angeles Tetela } \\
\text { El Aguacate }\end{array}$ \\
\hline $25 \mathrm{~km}$ & San Pedro Zacachimalpa & $\begin{array}{l}\text { Following communities can't be covered: } \\
\text { El Aguacate } \\
\text { Santa Maria Guadalupe Tecola }\end{array}$ \\
\hline $27 \mathrm{~km}$ & Santa Catarina & All communities are covered \\
\hline
\end{tabular}

\section{Conclusions}

When a public facility location problem arises, the main issue is to provide the proper coverage under a set of restrictions given by many conditions. These conditions and restrictions define the mathematical model to be used. However, an integration of multiple tools and techniques as well as an analysis is required to ensure that all variables that might affect the result are considered.

This research developed an analysis of current fire stations in Puebla City in order to recognize the coverage service and the need for new fire stations. It was found that due to population growth, some communities settled down in areas within the city that might not have a proper coverage, therefore a new fire station would have to be installed to provide the service. The characteristics of the problem indicated that the Maximal Covering Model was the most suitable to find the optimal location for the new facility. The results showed different scopes of coverage based on the distance limit. Although for emergency services, the fewer the time the fewer the risk, it is important to consider that we are looking for equilibrium, meaning to provide the service for as much communities as possible.

It is important to mention that the Fire Department of the Puebla City does not have (or was not allowed to provide due to security issues) a historical record of demand by type and area. That is why, for this research, this variable was not taken into account, however, we consider that having this type of data could have made a considerable change in the results. 


\section{References}

1. Rich, S., Davis, K.: Geographic Information Systems (GIS) for Facility Management. IFMA Foundation. Manhattan Software (2010)

2. Mosquera, P., Jennis, C.: Optimal areas determination for new fire stations located at Bogota based on special analysis tools. Universidad Militar Nueva Granada (2015)

3. Wei Gu, Xin Wan, S., McGregor, E.: Optimization of preventive health care facility locations. International Journal of Health Geographics (2010)

4. Church, R.L., ReVelle, C.: Maximal covering location problem. Papers of the Regional Science Association, 32 (1), pp. 101-118 (1974)

5. Coordinación Nacional de Protección Civil, CENAPRED: Atlas Nacional de Riesgos. Indicadores Municipales de Peligro, Exposición y Vulnerabilidad. Accessed June 17, 2016, http://www.atlasnacionalderiesgos.gob.mx/archivo/indicadores-municipales.html

6. Commission on Fire Accreditation, International Template: Standards of Response Coverage. Accessed June 25, https://www.iafc.org/files/1VCOS/sop_CPSE_CFAI_Standard_ of_Cover_Template.pdf

7. Daskin, M.S.: Network and discrete location: Models, Algorithms and Applications. John Wiley \& Sons, Inc., New York, 520 (1995)

8. Vitoriano, B.: Modelos Matemáticos de ayuda a la decisión en Logística Humanitaria. Depto. Estadística e Investigación Operativa I, Universidad Complutense de Madrid (2012)

9. Buzai, G.: Modelos de localización-asignación aplicados a servicios públicos urbanos: Análisis espacial de Centros de Atención Primaria de Salud en la ciudad de Bogotá (2011)

10. Owen, S.H., Daskin, M.S.: Strategic facility location: A review. European Journal of Operational Research, pp. 423-447 (1998)

11. Parvene, Z., Seyedeh, Z.: Analysis of the Spatial distribution and Locating fire stations, city Bracnch using GIS. Accessed July 29, 2016, ww.euromed.uk.com/files/documents/M105.pdf (2015) 